technological advance. There have been times when the stimulus was the other way round - particularly, for example, in the application of the steam engine to naval warfare.

McNeill sees military strength as being the principal reason for the internal security of rulers, at least until the middle of the twentieth century. However power may rest with a state for other reasons entirely; internal stability, for example, may follow because a regime has enjoyed an accepted legitimacy. Thus, states have held respected positions more because their systems of government were secure enough to develop effective military forces for external use, rather than because they could dominate their own populations militarily. The eighteenth century provides a classic example of this kind of effect, in which all states improved or wished to improve their internal administration. McNeill thinks that this was just because rulers had come to enjoy a complete internal security through their possession of more efficient armies. It is also true, however, that at that time states were facing an unprecedented problem of international relations in that, because of a shift in the distribution of power among them, they no longer faced a single threat but a multiple one in which each nation was equally feared and fearful. Then, as before and as now, internal efficiency and stability was one of the components of power and it was not surprising that anxious rulers should have attended to domestic reform more because of foreign threats than because they felt militarily predominant within their own borders.

A similar problem for McNeill's thesis occurs in late nineteenth-century Europe. He offers three causes for the First World War: first, a threat to the balance of power (which he regards as the least significant); secondly, changes in the structure of industry and state administrations induced by the demands of military developments, leading to a dysfunction between the striking success of industrial organizations in the advanced states and the increasing inability of those states to apply this advance to their relations with each other. Thirdly, a demographic crisis developed which could only be relieved by war or disease, both of which had occurred by 1918 . Here again, while accepting the importance of a demographic factor, we need to be reminded that the chief consequence of technological advances in the nineteenth century, particularly in communications, was a shift in the distribution of power in the world; it was this, rather than anything else that made states feel insecure. The defensive reaction of Germany to the rise of Russia in the early twentieth century exemplifies this effect. In such circumstances all states felt under pressure to make the most of their industrial capacity, their armed strength and their internal stability.

For McNeill, it is the consequence of fighting the two world wars rather than their causes which are profoundly signi- ficant, because those consequences amounted to an apotheosis of the pattern he has identified. Compelled by military necessities, states had to make fundamental changes in their administrations. This time the heady mixture of danger, patriotism and a formidable level of industrial and technological organization pushed them out of the old path of social and political development, carried on the back of intertwined economic and military change, into a new kind of mixed or semicommand economic and social structure. McNeill argues that since 1945 this situation has been maintained by military and technological pressures. The constant fear induced by nuclear weapons, and the enormous expenditure lavished on armaments generally, have led many to agree that this new structure, and other characteristics of contemporary political life, are militarily determined. Military force, however, is clearly not the only determinant of power and may have more significance as a reflection of its distribution. Some would say that the present baroque, even rococo, state of modern military competition is not just a consequence of the global power structure, but that its complexity reflects the fact that the power structure is less volatile than for many centuries past.

McNeill rightly stresses contemporary international tensions, and he has a prescription for their amelioration: world government, which, as he says, is certainly technically feasible. But the will is so lacking that the very prescription has a quackish air. More sensibly, he observes that it would be wise to expect the future to yield as many surprises as the past, some of them unpleasant. To any historian accustomed to working on any part of the last five centuries or so, the most surprising thing that could happen is that upheavals in human society should slow down and gradually stop. McNeill, however, does foresee this as the likely desirable consequence of the establishment of a world government, and allows that greater demographic control and the immobilizing nature of nuclear weapons have produced greater stability since 1945 .

Nuclear weapons may be about to be eclipsed by new weapons but forseeable technological developments are unlikely to disturb the current balance of power. If this is so, it will be likely to demonstrate that it is not any particular weapon that has been immobilizing, so much as the absence of any serious threat to the dominance of the super powers. They have now achieved an apparently impregnable position against which all the threats of the post-War world have proved ineffective. Perhaps McNeill might be most surprised by the prospect that this fact may eventually permit the natural development of the tranquillity which, for him, can only flow from an attractive but impractical dream.

Richard Langhorne, an historian, is a Fellow of St John's College, University of Cambridge.

\section{Jewish nationalism and the liberal ideal}

\author{
M.F. Perutz
}

The Essential Chaim Weizmann: The

Man, The Statesman, The Scientist. Compiled and edited by Barnet Litvinoff. Weidenfeld \& Nicolson: 1983. Pp. 290. f16.50.

The Essential Chaim Weizmann conjures up a vivid image of the great Jewish leader, mostly by letting him speak in his own words. It quotes extracts from his speeches, letters and memoirs; it adds summaries of his career, of his political battles with successive Zionist Congresses, and of his brilliant negotiations leading first to the Balfour Declaration and later to recognition of Israel as an independent state. It contains an appreciation, in no more than three pages, of Weizmann's scientific work, and it reproduces a variety of people's sketches of Weizmann's personality. Appendices give the texts of several official documents, from the Faisal-Weizmann agreement in 1919 to Israel's Proclamation of Independence of 1948.

Weizmann had a fervent belief that the Jews were a nation entitled to the rights of a nation; at the same time he was inspired by liberal ideals and averse to any form of violence. His high moral standards can be gauged from his courageous address to the Zionist Congress of 1946 , at a time when the British Labour Government was blocking Jewish immigration into Palestine and bitterness was at its height:

It is difficult in such circumstances to retain a belief in the victory of peaceful ideals, in the supremacy of moral values. And yet I affirm . that we must retain it. Zionism is a modern expression of the liberal ideal. Divorced from that ideal it loses all purpose, all hope. Assassination, ambush, kidnapping, the murder of innocent men, are alien to the spirit of our movement . . . it mocks the ideals for which a Jewish society must stand.

Already in 1929 Weizmann had written to Einstein: "I have always preached most unpopular realities to the Zionists, have always been attacked most bitterly . . .". For example he told the Congress in 1923:

Palestine is not an empty country . . . there are 500,000 Moslems, 100,000 Christians and a 100,000 Jews . . . there has been a striving on the part of the Arab people for a revival . . . being anxious for a revival of the scattered Jewish people, we treat with respect and reverence any attempt at revival amongst other people.

In his autobiography, Trial and Error (Hamish Hamilton, 1949), Weizmann wrote:

We must stand by the ancient principle enunciated in our Torah: "One law and one manner shall be for you and for the stranger that sojourneth with you ...". I am certain that the world will judge the Jewish State by what it does to the Arabs. 


\section{IMAGE \\ UNAVAILABLE FOR COPYRIGHT REASONS}

Chaim Weizmann is sworn in as the first President of Israel, 15 February 1949. "We must stand by the ancient principle enunciated in our Torah: "One law and one manner shall be for you and for the stranger that sojourneth with you ... . I am certain that the world will judge the Jewish State by what it does to the Arabs".

There is never a word about the Jews being the Chosen People. He regarded Menahem Begin as "a megalomaniac suffering from a Messianic complex".

Though Weizmann was fond of quoting the prophets, he rarely appealed to God. I gained the impression that he was an agnostic at heart and believed in a secular Judaism as a cultural bond that welds the world's Jews into a single nation. His opposition to bigoted orthodoxy first emerges from a letter to Theodor Herzl in 1903 :

If there is anything in Judaism that has become intolerable and incomprehensible to the best Jewish youth, it is the pressure to equate its essence with the religious formalism of the orthodox.

In 1949 he wrote:

It is the new, secularized type of rabbi . . who will make a heavy bid for power by parading his religious convictions. ... they transgress a fundamental principle which has been laid down by our sages: "Thou shalt not make of the Torah a crown to glory in, or a spade to dig with".

Weizmann was born and raised in the Pale of Settlement "that prison house created by Tsarist Russia for the largest part of its Jewish population"'. He escaped as an 18-year-old - on a timber barge going down the Vistula - to study chemistry in Germany, determined to raise the Jews to a nation equal in rank with other nations. In his eagerness to awaken Jews all over the world to a national consciousness, and to preserve Jewish culture and heritage in a sovereign Jewish state, he was intolerant of those who have become assimilated to the countries they live in. "I don't care what will happen to the Jewish communities in England or in France ... their highest ideal is assimilation, disintegration, dissolution". By contrast it seems to me that all the world's Jews could not find refuge in Palestine even if they wanted to, and that by failing to assimilate they will keep antisemitism alive for ever. As Boris Pasternak makes Dr Zhivago say:

Why don't the intellectual leaders of the Jewish people . . . say to the Jews: Don't hold on to your identity, don't all get together in a crowd. Be with all the rest . . . . What the Gospels tell us is . . that there are no nations, only people.

In the Balfour Declaration the extent of the Jewish National Home had been left open. Weizmann hoped that it would include a much larger area than the present state of Israel. The Turkish province of Palestine included both $\mathrm{Cis}$ and Transjordan, and at the Versailles Peace Conference in 1919 Weizmann pleaded that all territory west of the Hedjaz railway, which runs from Aqaba via Amman to Damascus, should be included in the National Home. Today this may sound like imperialism, but judged by the nonchalance with which Lloyd George and Clemenceau disposed of the former Turkish Empire by carving it up between them, Weizmann's claim to the whole of Palestine seems less unreasonable now than, say, France's to Syria and the Lebanon. According to Asquith, Lloyd George backed Weizmann, though he "does not care a damn for the Jews, but thinks it an outrage to let the Holy places pass into the possession of agnostic, atheistic France". However Sir Isaiah Berlin believes that Asquith traduced Lloyd George who did not like the English establishment and had a certain fellow feeling for minorities treated de haut en bas by grand Englishmen such as Lord Robert Cecil.

The opening, in 1925, of the Hebrew University on Mount Scopus, for which Weizmann had campaigned since 1902, was one of his life's great triumphs. "Our Hebrew University ... will have a centripetal force, attracting all that is noblest in Jewry throughout the world"'. Litvinoff's book might have included more about Weizmann's labours for the other two academic institutions that have made Israel a sturdy outpost of science and learning, the Weizmann Institute of Science and the Haifa Technion.

Weizmann was a phenomenon. He arrived in London in 1904 as a promising young chemist and found an appointment as a research fellow at Manchester University the following year. He proved himself a highly original and inventive scientist. Thirteen years later he had pledged the British Government to the establishment of a Jewish National Home in Palestine. How did he, an immigrant Russian and self-appointed leader of the world's Jews, achieve this triumph? He did it single-handed, aware, perhaps, of Francis Bacon's dictum: "In all negotiations of difficulty, a man may not look to sow and reap at once, but must prepare business and so ripen it by degrees". For much of the time he was at loggerheads with, rather than backed by, a bickering Zionist Congress. It seems that he was a born statesman whose force of personality made other statesmen accept him on his own terms. In his book Chaim Weizmann (Weidenfeld \& Nicolson, 1958), Isaiah Berlin has described how

his method of argument was ... neither a demonstration founded on ... documented evidence, nor emotional rhetoric, nor a sermon ...; it consisted in painting a ... vivid, detailed, coherent, concrete picture of a given situation or course of events; and his interlocutors ... felt that this picture ... conformed to their own experience of what men and events were like, of what had happened, or might happen, or . . . could not happen. The moral, historical, economic, social and personal factors were blended in Weizmann's remarkable . . . expositions much as they combine in life.

Yet in the critical years after 1938 Weizmann failed to persuade British leaders to open the gates of Palestine either to the Jews threatened by the holocaust or to its survivors. Torn between his passionate devotion to the Jewish cause and his admiration for Britain, the country that embodied his liberal ideals, he became estranged from both his English and his Jewish friends. This tragedy clouded the last years of his life and is movingly described in Berlin's book, but rather glossed over by Litvinoff.

Weizmann's tremendous moral courage and supreme confidence in his own persuasive powers made him plead his case with political leaders as diverse as Lloyd George, Franklin Roosevelt, Benito Mussolini and Ibn Saud. Ben Gurion wrote of him:

I never failed to be astonished by his inner forcefulness, by his determined manner. He could be angry with these men in power . . . but his anger emerged with such natural dignity that it was always deeply moving.

Lord Robert Cecil wrote of his subdued enthusiasm and the extraordinary impressiveness of his attitude "which make one forget his rather repellent and even sordid exterior". General Smuts, another statesman with whom Weizmann made friends, wrote this epitaph: "He was the greatest Jew since Moses". I wish that the ideals for which he stood would still guide Israel's rulers today.

M.F. Perutz is at the Medical Research Council Laboratory of Molecular Biology, Cambridge, $U K$. 